\title{
STABILITY AND PERFORMANCE OF PALM- BASED TRANSPARENT SOAP WITH OIL PALM LEAVES EXTRACT
}

\author{
NORASHIKIN AHMAD*; ZAFARIZAL ALDRIN AZIZUL HASAN* and SITI HAJAR BILAL*
}

\begin{abstract}
Oil palm leaves (OPAL) is one of the oil palm waste components that can be extracted for natural phenolics. The OPAL extracts have been successfully extracted via four different extraction procedures; extraction with ethanol (OPAL M1), deoiled and followed by extraction with ethanol (OPAL M2), deoiled and extraction with ethanolic hydrochloric acid (OPAL M3) and aqueous extraction (OPAL M4). In this study, pH, moisture content, hardness, foaming power and stability, antioxidant activity and colour stability of transparent soaps with OPAL extracts were carried out. The results indicated that all transparent soaps with OPAL extracts had similar $p H$ in the range of 9.88 to 9.98. However, there was a significant reduction of moisture content (14.6\%-16.7\%) compared to transparent soap control (18.3\%) due to the evaporation of water during the melting and mixing. The hardness of transparent soaps with OPAL M3 and OPAL M4 was found to be softer than transparent soaps with OPAL M1 and OPAL M2. By adding OPAL extracts, the foaming ability and stability were not affected. Transparent soap formulated with OPAL M1 extract exhibited the highest percentage of antioxidant activity (3.7\%). The use of OPAL extracts is recommended in transparent soap as it provides natural colourant.
\end{abstract}

Keywords: foaming, OPAL extracts, transparent soap.

Received: 17 November 2020; Accepted: 1 March 2021; Published online: 19 May 2021.

\section{INTRODUCTION}

Malaysia and Indonesia contribute $80 \%$ of world palm oil production and dominate international trade. Sustainability and environmental issues demand the oil palm industry to look for the latest technologies, beneficial nutritional aspects, and producing value-added products for niche and new markets (Parveez et al., 2020). Thus, oil palm leaves (OPAL) are a by-product of the oil palm industry, which can be exploited for the extraction of phenolics. Several studies reported that OPAL extract is rich in antioxidant activity ( $\mathrm{Ng}$ and Choo, 2010), shows anti-microbial activities towards gram-positive bacteria with good UVA and UVB

\footnotetext{
Malaysian Palm Oil Board,

6 Persiaran Institusi, Bandar Baru Bangi,

43000 Kajang, Selangor, Malaysia.

E-mail: shikin@mpob.gov.my
}

protection for topical applications (Yusof et al., 2016).

Soap is the first skin cleansing agent, discovered by Babylonians as early as $2800 \mathrm{BC}$. They made soap from boiled animal fats with wood ashes. Then, around 1500 BC, Egyptians used vegetable or animal oil and alkaline salts to produce soap with a high $\mathrm{pH}$ value for bathing, washing, and treatment of skin diseases. Generally, soap can be produced from three different routes, i.e., saponification of oils, neutralisation of fatty acids and saponification of fatty methyl ester. Soap is the ultimate environmentally friendly surfactant because of its simple and cheap production, excellent biodegradability, low toxicity and has excellent surfactant properties (Wolfrum et al., 2016). Solid soaps are available in the form of opaque, translucent and transparent soap. However, transparent soap is preferred due to luxurious appearance and sold at 
the upper-middle market segment as beauty soap (Hasibuan et al., 2014). Besides, transparent soap contains a high amount of glycerin which functions as a humectant to counter the drying effects of soap towards the skin.

Soap is commonly used to reduce water surface tension and to lift dirt and oils off from our skin surface so that it can be easily rinsed away. In order to add value to the traditional soap, active ingredients from plant extract were introduced to promote healthy skin. Nowadays, cosmetic products with plant bioactive are receiving higher market demand (Emerald et al., 2016). The inclusion of plant extracts in topical formulations as a source of vitamins, antioxidants and antimicrobials have been shown to improve skin tone, texture and appearance of human skin (Ribeiro et al., 2015). It is well known that plant extracts are a valuable source of active compounds such as phenolics, which function as antioxidants. Many studies have been reported on the effectiveness of plant extracts, especially leaf extract in soap formulation. Pomegranate (Punica granatum) leaves extract was formulated in liquid and bar soaps and displayed antibacterial and antioxidant activities, whereas the solid soap only displayed antioxidant activity (Wijetunge and Perera, 2016). A combination of leaf and bark extracts of Cassia fistula, Ficus religiosa and Millettia pinnata in transparent soap were reported to have good antimicrobial effect (Afsar and Khanam, 2016). Anggraini et al. (2015) studied the characteristics and antioxidant activity of green tea leaf extract in transparent soap, and they found that $2 \%$ of green tea extract has higher antioxidant activity $(15.21 \%$ 2,2-diphenyl-1-picrylhydrazyl (DPPH) scavenging activity) compared to transparent soap without green tea extract $(0.83 \%$ DPPH scavenging activity). The antioxidant was used in soap formulation to prevent the oxidation of unsaturated fatty acids and enhance soap shelf life (Adigun et al., 2019). Another common antioxidant used in soap products is butyl hydroxy toluene (BHT). However, this synthetic antioxidant was not popular in topical applications because it may induce allergic reactions to the skin (Yamaki et al., 2007).

OPAL extract is also a potential new source of antioxidants for food and cosmetic applications. In 2011, Jaffri et al. analysed the composition of OPAL extract using high-performance liquid chromatography and found that the main phenolic compounds were epigallocatechin $(0.08 \%)$, catechin $(0.30 \%)$, epicatechin $(0.01 \%)$, epigallocatechin gallate $(0.28 \%)$ and epicatechin gallate $(0.05 \%)$. In 2018, Ahmad et al. studied the effect of OPAL extract on the colour of transparent soap. The results showed that $0.1 \%$ OPAL extracts gave a better and acceptable colour compared to $0.5 \%$ OPAL extracts. However, the researchers did not investigate the stability and performance of the transparent soap with OPAL extracts. It is important to ensure that the formulated soap with OPAL extracts has good stability and functionality. In this study, $0.1 \%$ of OPAL extracts prepared from four different extraction methods were used in transparent soap formulation. The purpose of this study was to investigate the effects of OPAL extracts on the quality of transparent soap such as $\mathrm{pH}$, hardness, moisture content, foaming ability, anti-oxidant and colour stability compared to control and soap with synthetic antioxidant.

\section{MATERIALS AND METHODS}

\section{Chemical and Apparatus}

OPAL powder was obtained from Fyllo (M) Sdn. Bhd. Hexane was purchased from Fisher Scientific, USA. Ethanol with $99.9 \%$ purity, was obtained from ACI Labscan, Thailand. Sodium hydroxide $(\mathrm{NaOH})$ with $99 \%$ purity was obtained from Merck, Germany. BHT with $99 \%$ purity was obtained from Sigma-Aldrich, Germany. Commercial green tea extract with known composition (water, propylene glycol, $25 \%$ of green tea extract, phenonip and EDTA) was purchased from Active Concepts, USA. DPPH radical was supplied from Sigma-Aldrich, USA. Fatty acids were purchased from Emery Oleochemicals (M)Sdn. Bhd. Glycerin was purchased from Croda, Singapore. Ethylenediaminetetraacetic acid disodium salt (EDTA) was purchased from Ajax Finechem Pty Ltd, Australia. Sodium laureth sulfate (SLES) was purchased from BASF, Germany and lactic acid was obtained from Purac Biochem, United Kingdom. Deionised water was used in this study. The spectrophotometric determination was performed on a UV-Visible Spectrophotometer, model UV-1800 from Shimadzu Corporation, Japan. Chroma Meter CR300, Konica Minolta, Inc. Japan was used to measure the colour luminosity of transparent soap. Texture analyser TA.XT plus from Micro Stable Systems, United Kingdom was used to measure the hardness of soap. While the $\mathrm{pH}$ of the soap solution was measured using $\mathrm{pH}$ meter by Mettler Toledo AG, Switzerland. Moisture analyser (XM50 from Precisa Gravimetrics AG, Switzerland) was used to measure the moisture content of transparent soap.

\section{Preparation of Transparent Soap Base}

The transparent soap base was prepared according to the method described by Ahmad et al. (2018). Briefly, 29\% (w/v) sodium hydroxide solution was added into the melted fatty acids to form soap. Then, a premixed solution containing glycerin, EDTA, water, and SLES was added into the vessel. The mixture was heated and stirred to obtain a homogeneous solution. Lactic acid was used to 
adjust the $\mathrm{pH}$ of the mixture to $\mathrm{pH}$ 9-10. Lastly, the mixture was poured into a mould and cooled down to room temperature (RT). The solid transparent soap base was wrapped with plastic to avoid sweating.

\section{OPAL Extracts}

In this study, four extraction methods of OPAL, as described by Ahmad et al. (2018), were adopted without any modification. OPAL M1 was prepared by extracting $20 \mathrm{~g}$ OPAL powder in $200 \mathrm{ml}$ ethanol at $78^{\circ} \mathrm{C}$ for $2 \mathrm{hr}$. OPAL M2 was prepared by soaking $20 \mathrm{~g}$ OPAL in $200 \mathrm{ml}$ hexane at RT overnight to remove fatty materials. Then, the phenolics were extracted in $200 \mathrm{ml}$ ethanol at $78^{\circ} \mathrm{C}$ for $2 \mathrm{hr}$. The phenolic extraction method for OPAL M3 was similar to the OPAL M2, but $5 \mathrm{ml}$ of $6 \mathrm{M} \mathrm{HCl}$ was introduced during the extraction of phenolic. Lastly, OPAL M4 was prepared by mixing $20 \mathrm{~g}$ OPAL powder with $200 \mathrm{ml}$ deionised water at $100^{\circ} \mathrm{C}$ for 2 hr. All the crude OPAL extracts obtained were stored in the dark at RT.

\section{Preparation of Transparent Soaps with OPAL Extract, BHT and Commercial Green Tea Extracts}

Six transparent soaps were prepared namely base soap without active (control), blend of transparent soap base with $0.1 \mathrm{~g}$ of OPAL extracts (OPAL M1, OPAL M2, OPAL M3, and OPAL M4), soap base with $0.1 \mathrm{~g}$ of BHT and soap base with commercial green tea extract. About $100 \mathrm{~g}$ of transparent soap base was melted at temperature $60^{\circ} \mathrm{C}-70^{\circ} \mathrm{C}$. Then, the active was added into the melted soap. The homogeneous mixture was poured into a mould and cooled to RT. The soap was wrapped with plastic after the soap had hardened and stored in a box at RT for analysis. Table 1 shows the soap samples prepared for this study.

TABLE 1. TRANSPARENT SOAP SAMPLES

\begin{tabular}{|c|c|}
\hline $\begin{array}{c}\text { Transparent } \\
\text { soap }\end{array}$ & Description \\
\hline Control & Soap base (without active) \\
\hline S1 & Soap base with $0.1 \mathrm{~g}$ of OPAL M1 \\
\hline S2 & Soap base with $0.1 \mathrm{~g}$ of OPAL M2 \\
\hline S3 & Soap base with $0.1 \mathrm{~g}$ of OPAL M3 \\
\hline S4 & Soap base with $0.1 \mathrm{~g}$ of OPAL M4 \\
\hline S5 & Soap base with $0.1 \mathrm{~g}$ of BHT \\
\hline S6 & $\begin{array}{l}\text { Soap base with } 0.1 \mathrm{~g} \text { of commercial green } \\
\text { tea extract }\end{array}$ \\
\hline
\end{tabular}

pH

The $\mathrm{pH}$ of soap solution was determined using a $\mathrm{pH}$ meter (Mettler Toledo AG, Switzerland). Buffer solutions $\mathrm{pH} 4$ and 7 were used to calibrate the $\mathrm{pH}$ meter. Electrode InLab ${ }^{\circledR}$ Routine Pro was washed with distilled water and dried. The soap solution was prepared by diluting $1.0 \mathrm{~g}$ of soap sample in $10 \mathrm{ml}$ of distilled water. The $\mathrm{pH}$ meter electrode was dipped into the soap solution, and the $\mathrm{pH}$ was recorded after constant reading was achieved.

\section{Hardness}

The hardness of transparent soap without OPAL extracts, with OPAL extracts, BHT and commercial green tea extract were evaluated by penetration method using a texture analyser TA.XT plus (Micro Stable Systems, UK). A stainlesssteel needle $(\mathrm{P} / 2 \mathrm{~N})$ with a diameter of $2 \mathrm{~mm}$ was used for the measurement. The needle was dipped $7 \mathrm{~mm}$ into a soap sample with a moving rate of $2 \mathrm{~mm} \mathrm{~s}^{-1}$. The test was carried out at RT. This method was adapted from ASTM standard method D1321-95. The maximum force was defined as hardness. The data were expressed in Newton (N).

\section{Moisture Content}

The moisture content of transparent soap, with and without OPAL extracts and soap with BHT and commercial green tea extract was determined by using a moisture analyser (XM50 from Precisa Gravimetrics AG, Switzerland) with a halogen heater. Two $g$ of soap sample was accurately weighed with a precision of $1.0 \mathrm{mg}$ and placed in aluminium dishes in the moisture analyser. The temperature of heating was $105^{\circ} \mathrm{C}$. The weight of the soap sample was measured once it has reached constant weight $(\mathrm{g})$. The result is represented in $\%$ of moisture content and reported in average value.

\section{Foaming Power and Stability}

The foaming power and stability of soap solutions were assessed using a method developed by Benn et al. (2017) with slight modification. Foaming power is a measure of foam height taken immediately after $200 \mathrm{ml}$ of the test solution was stroked for 30 times at a constant rate using a perforated base rod. The test solution was prepared by dissolving $0.5 \mathrm{~g}$ of product with $200 \mathrm{ml}$ of water in a $500 \mathrm{ml}$ measuring cylinder. The foam was let to rest for $5 \mathrm{~min}$ before the foam height was measured, which indicated foam stability. The analysis was performed in triplicate and data reported the average value. The foaming power and foam stability of the transparent soaps with OPAL extracts were tested in deionised water and $50 \mathrm{ppm}$ water hardness (water with calcium carbonate, $\mathrm{CaCO}_{3}$ ). 


\section{Antioxidant Activity}

The method for antioxidant activity, as described by Enujiugha et al. (2012) was adopted with few modifications. An ethanolic solution of DPPH $(18.18 \% \mathrm{v} / \mathrm{v})$ was prepared and stored at $10^{\circ} \mathrm{C}$ in the dark. Soap samples were prepared in ethanol solution with a concentration of $2 \mathrm{mg} \mathrm{ml}^{-1}$. About $0.15 \mathrm{ml}$ of the sample solution was then added to a $2.85 \mathrm{ml}$ ethanolic DPPH solution. The mixture was shaken and left to stand at RT for $1 \mathrm{hr}$ in the dark. The colour changes from deep violet to light yellow were measured spectrophotometrically at $515 \mathrm{~nm}$. The absorbance of DPPH solution without soap sample (control), soap without OPAL extracts, soap with BHT and soap with commercial green tea extract were also measured. All measurements were performed in three replicates and the average was counted. The percentage of inhibition of the DPPH was calculated according to the formula as followed:

DPPH inhibition, $\%=\left[\frac{\mathrm{A}_{\text {(control) }}-\mathrm{A}_{\text {(sample) }}}{\mathrm{A}_{\text {(control) }}}\right] \times 100$

where $\mathrm{A}_{\text {(control) }}$ is the absorbance of the control, and $\mathrm{A}_{\text {(sample) }}$ is the absorbance of the sample.

\section{Colour Stability}

Colour stability of the soap was evaluated at Day 7 and monthly for 3 months. The measurement was carried out using a Chroma Meter CR300 (Minolta, Japan). The Chroma Meter measures the sample surface of $8 \mathrm{~mm}$ in diameter at wavelengths $(400-700 \mathrm{~nm})$ of transmitted light, standard observer $\left(0^{\circ}\right)$, under illuminant D65 and white plate calibration. The soap was placed on a white tile and measurement was taken from the top of the soap. The readings of the soap samples were recorded in the CIELAB system in the form of $L^{*}$ and $b^{*}$ values. The system measures $L^{*}$ which refers to luminosity black $(0)$ to white $(100)$ and $b^{*}$ positive which refers to yellow colour. A total of ten readings were taken and a mean value was calculated. Yellowness Index (YI) which indicates the degree of yellowness was determined using Equation 1 (Rhim et al., 1999).

$$
\mathrm{YI}=142.86 \mathrm{~b}^{*} / \mathrm{L}^{*}
$$

Equation (1)

where $b^{*}$ is the yellow colour scale, and $L^{*}$ is the luminosity scale.

\section{Statistical Analysis}

The data obtained from the above studies were analysed statistically using Microsoft Excel version 2013 for Analysis of variance (ANOVA) single factor and Student t-Test. The differences were considered significant if the probability, $\mathrm{p}<0.05$.

\section{RESULTS AND DISCUSSION}

\section{pH and Moisture Content of Transparent Soap}

The $\mathrm{pH}$ and moisture content of transparent soap samples were determined after one week of storage at RT. The results obtained from analyses of $\mathrm{pH}$ and moisture content of transparent soaps are presented in Table 2. The $\mathrm{pH}$ of all transparent soaps analysed in this study fall within the range between 9.88 and 10.02. It was observed that the addition of $0.1 \%$ OPAL extracts, BHT and commercial green tea extract in the transparent soap have significantly reduced the $\mathrm{pH}$ of soap samples compared to control. In the preliminary screening of five different commercial transparent soaps which were sourced locally, the $\mathrm{pH}$ of the soaps was determined in the range of 9.19-9.60. Kulthanan et al. (2014) reported that the $\mathrm{pH}$ for bar soaps marketed in Thailand was in the range of 9.8 to 11.3. In addition, Dlova et al. (2017) reported that commercial bar soaps obtained in South Africa had $\mathrm{pH}$ values ranging from 9.36 to 10.75. Thus, the $\mathrm{pH}$ of the formulated transparent soaps in this study is in agreement with the commercial bar soaps. Several studies have shown that the use of alkaline soaps increases skin $\mathrm{pH}$. Korting and co-workers in 1990 and 1996 reported the impact of long-term and short-term effects of alkaline ( $\mathrm{pH} 8.5)$, acidic ( $\mathrm{pH} 5.5)$, and neutral $(\mathrm{pH}$ 7.0) cleansers on skin $\mathrm{pH}$. It was reported that skin $\mathrm{pH}$ increased significantly after washing with alkaline cleanser. However, a slight increase was also found after the usage of an acidic product as well as after washing the skin with a neutral cleanser. Another study carried out by Takagi et al. (2015) found that continuous application of soap at $\mathrm{pH} 10.3$ for $6 \mathrm{hr}$ did not adversely affect the skin $\mathrm{pH}$. After $6 \mathrm{hr}$, the skin $\mathrm{pH}$ returns to normal acidic conditions. Thus, the alkaline $\mathrm{pH}$ of soap does not significantly affect healthy skin.

ABLE 2. MEAN pH AND MOISTURE CONTENT OF TRANSPARENT SOAPS

\begin{tabular}{ccc}
\hline $\begin{array}{c}\text { Transparent } \\
\text { soap }\end{array}$ & Mean pH \pm SD & $\begin{array}{c}\text { Mean moisture } \\
\text { content }(\%) \pm \text { SD }\end{array}$ \\
\hline Control & $10.02 \pm 0.01^{\mathrm{a}}$ & $18.36 \pm 0.27^{\mathrm{a}}$ \\
S1 & $9.88 \pm 0.03^{\mathrm{b}}$ & $14.64 \pm 0.09^{\mathrm{b}}$ \\
S2 & $9.90 \pm 0.02^{\mathrm{b}}$ & $15.70 \pm 0.10^{\mathrm{c}}$ \\
S3 & $9.93 \pm 0.03^{\mathrm{b}, \mathrm{d}, \mathrm{e}} \mathrm{e}$ & $15.72 \pm 0.23^{\mathrm{c}}$ \\
S4 & $9.96 \pm 0.01^{\mathrm{c}}$ & $16.73 \pm 0.12^{\mathrm{d}}$ \\
S5 & $9.98 \pm 0.01^{\mathrm{d}}$ & $16.68 \pm 0.10^{\mathrm{d}}$ \\
S6 & $9.92 \pm 0.01^{\mathrm{e}}$ & $18.31 \pm 0.35^{\mathrm{a}}$ \\
\hline
\end{tabular}

Note: Values with the same superscript letter are not statistically significant at the 5\% level; SD - standard deviation. 
Table 2 shows that the mean moisture content of transparent soap S1 - S5 reduced significantly compared to control and transparent soap S6. These variations may be due to the evaporation of water during melting of the soap base and mixing of active. It was observed that the transparent soap S1 had the lowest moisture content. According to Ahmad et al. (2018), the OPAL M1 was waxy, and thus incorporation of this active into transparent soap needs prolonged heating, which resulted in low moisture content. However, commercial green tea extract was easy to mix with the soap base. Thus, less evaporation of water was observed for transparent soap S6. The transparent soaps moisture content falls within the range reported by Kuntom et al. (1996), which was 8\%-14\%. It was reported that the appearance of active, either waxy or not, also affected the moisture content of transparent soap. The moisture content values of all transparent soap samples in this study are within the ranges obtained by Vivian et al. (2014) i.e. 10.91\%-22.69\% moisture for the commercial soap sold in Kenya, Osuji et al. (2013) i.e. $18.3 \%-22.5 \%$ moisture for soap with palm oil sludge, tallow and palm kernel oil as well as Kuntom and Kifli (1998) i.e. 10\%-18\% moisture for the soap blends with palm stearin and palm kernel fatty acids.

\section{Physical Properties of Soap}

The results from the analyses of hardness for palm-based transparent soap with $0.1 \%$ of OPAL extracts, $0.1 \%$ commercial green tea, BHT and control are depicted in Figure 1. A reduction in penetration force indicates that the soap is softer, as less force is used to penetrate a fixed distance. It was observed that the addition of OPAL extracts, BHT and commercial green tea extract into the transparent soap base significantly reduced the hardness of bar soap compared to control at seven days of storage. In accordance with the present results, a previous study by Anoggraini et al. (2015) has demonstrated that the addition of green tea extract in transparent soap reduced the soap hardness. A possible explanation for this result is that the addition of an active ingredient in the form of liquid may cause a reduction in soap hardness. In addition, the results of this study showed that the hardness of palmbased transparent soap remained stable during the six months storage and within the average hardness for commercial transparent soaps in Malaysia which is $3.80-6.96 \pm 0.01 \mathrm{~N}$.

Besides hardness, palm-based transparent soaps with $0.1 \%$ of OPAL extracts, $0.1 \%$ commercial green tea extract, BHT and control were also assessed for their foaming ability and foam stability in deionised water versus $50 \mathrm{ppm}$ water hardness (Figure 2). The water hardness will prevent the lathering of soap (Srinivasan et al., 2013). Thus, the study was carried out to determine whether hard water would adversely affect the lathering of palm-based transparent soap. The water hardness concentration of $50 \mathrm{ppm}$ of $\mathrm{CaCO}_{3}$ was chosen in this study based on a survey carried out by Ong et al. (2007), which reported that the hardness of tap water in Klang Valley, Malaysia was in the range of 48-92 ppm of $\mathrm{CaCO}_{3}$. Based on this study, there was a statistically significant difference in foam performance of palm-based transparent soap in deionised and hard water, where the presence of 50 ppm $\mathrm{CaCO}_{3}$ decreased the foaming power and foam stability of palm-based transparent soap samples. Based on analysis of variant, there is no significant difference in foaming ability and foam stability for the palm-based transparent soap with OPAL extracts (S1 - S4) and control. Thus, indicating that the addition of OPAL extracts did not affect foaming power and foam stability.

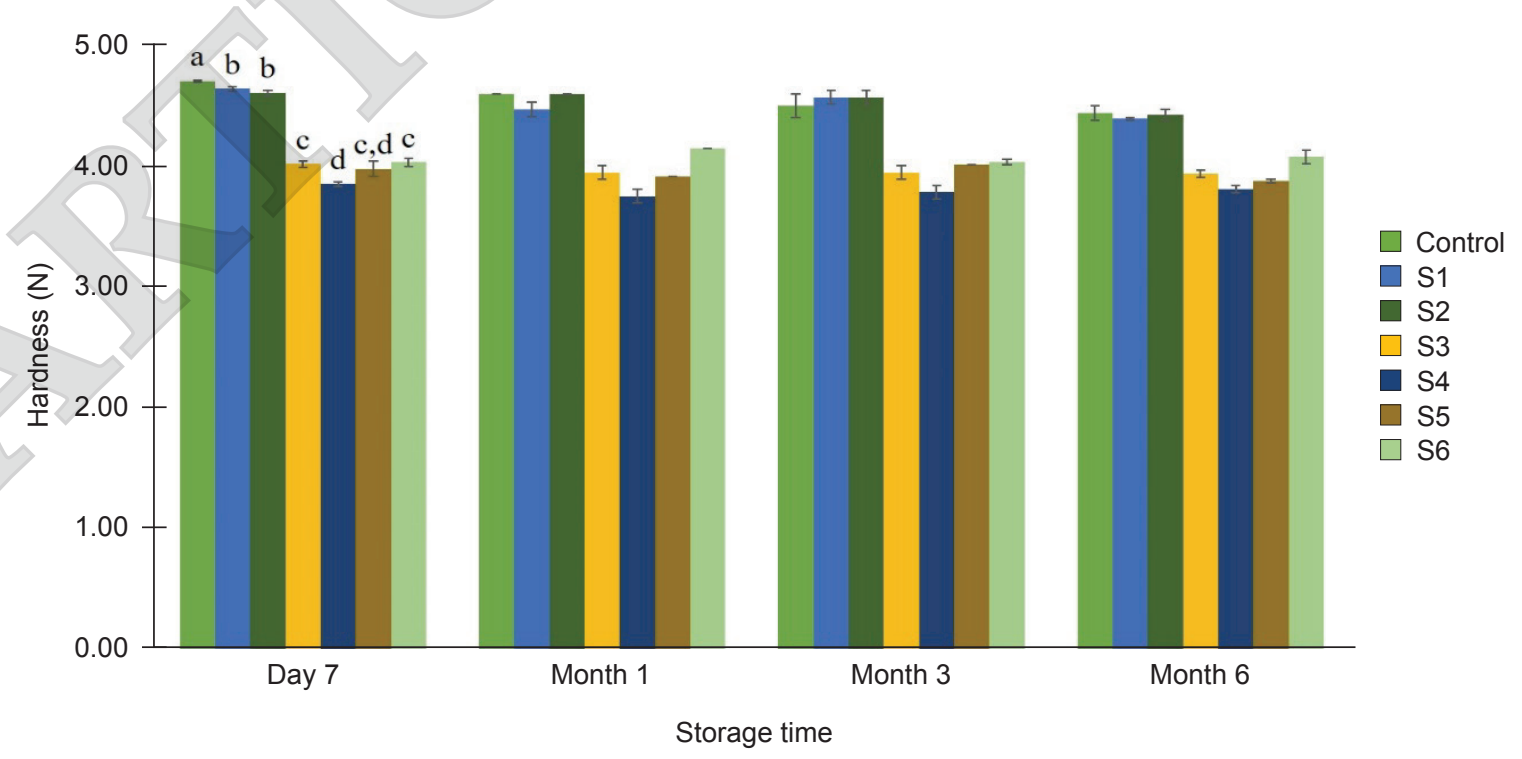

Figure 1. The hardness of palm-based transparent soap with $0.1 \%$ of OPAL extracts, $0.1 \%$ commercial green tea, BHT and control. Lower hardness value indicates the softness of soap. Values with the same superscript letter are not statistically significant at the 5\% confidence level. 


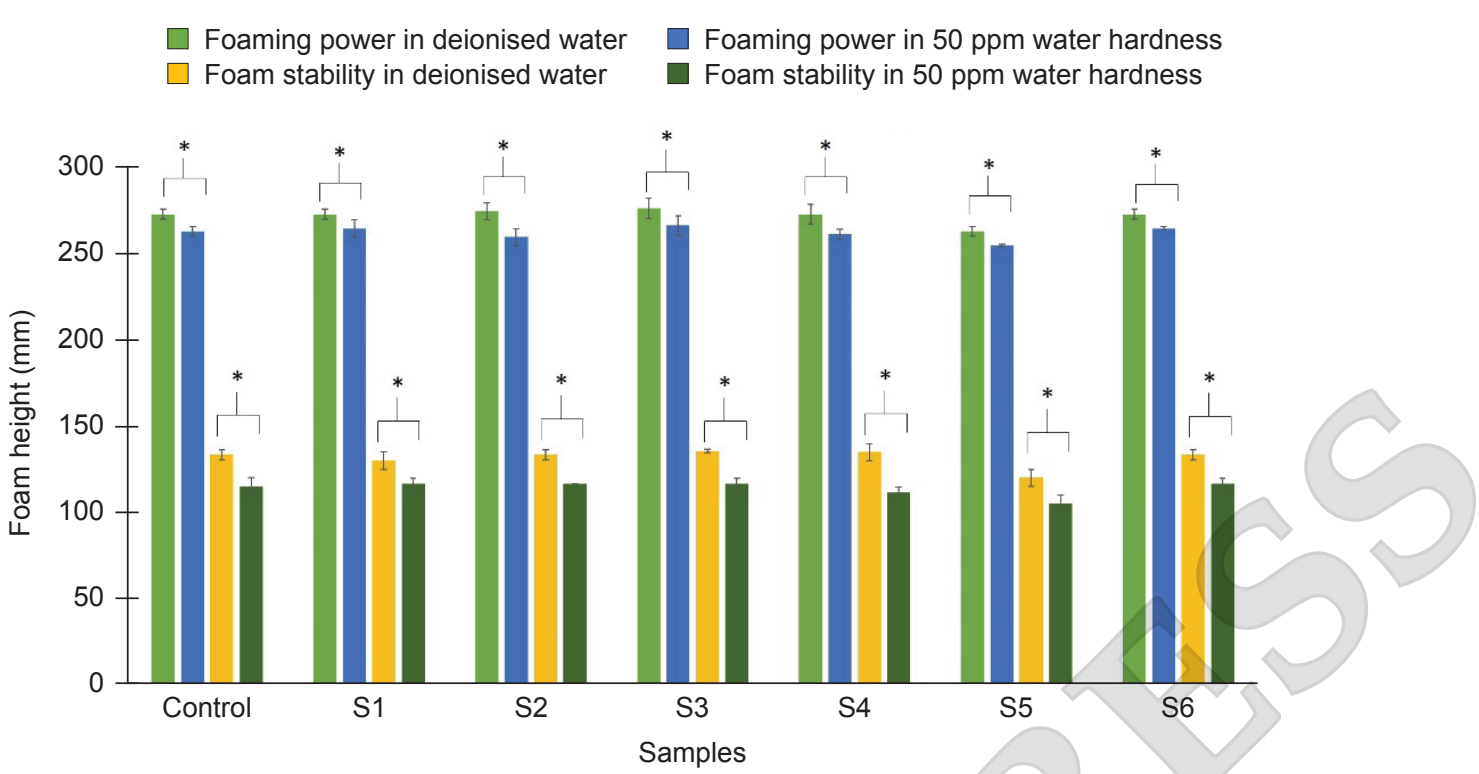

Figure 2. Foaming power and stability of palm-based transparent soap with $0.1 \%$ of OPAL extracts, $0.1 \%$ commercial green tea extract, BHT and control in deionised water vs. 50 ppm water hardness. ${ }^{*}$ statistically significant at the 5\% confidence level.

\section{Antioxidant Activity}

The addition of OPAL extracts in transparent soap was determined for their capacity to inhibit DPPH radicals and transparent soaps with BHT and green tea extract were selected as the benchmarks. BHT is a synthetic antioxidant, extensively used in many cosmetic and food products due to its chemical stability and inexpensive (Yamaki et al., 2007; Ghosh et al., 2020). While commercial green tea extract was chosen due to the known composition of the ingredient and commercially available extract. Based on these results, it was found that the addition of OPAL extracts into transparent soap significantly helped to increase the antioxidant activity (Table 3). In addition, S1 soap formulated with OPAL M1 extract exhibited the highest DPPH inhibition compared to other soaps with OPAL extracts and transparent soap with green tea extract. Irine et al. (2003) ascribed that OPAL extract has $8 \%$ higher content of phenolic compounds than green tea. Fadda et al. (2014) studied the reaction time and kinetic behaviour of plant extracts (green tea, pomegranate and lemon) with DPPH radical. They reported that the antioxidant activity was strongly influenced by DPPH concentration and reaction time. They also presented plant extracts that will perform either fast or slow kinetic behaviour. Thus, the antioxidant activity of transparent soap with green tea probably has slow kinetic behaviour, which may need more than $1 \mathrm{hr}$ to react with DPPH radical. In addition, the commercial green tea extract contains 25\% active material. Due to the low content of the active ingredient, it has caused low antioxidant activity. Since the purpose of this work is to investigate the antioxidant activity of transparent soap with OPAL extracts, so we have not investigated a proper reaction time for transparent soap with green tea. However, the antioxidant activity of soap with OPAL extracts was still lower than soap formulated using synthetic antioxidant, BHT. Fatiha and Abdelkader (2019) reported that BHT would react rapidly with DPPH and gave the highest DPPH inhibition compared to other compounds, which may require longer reaction times and higher concentrations.

\begin{tabular}{cc} 
TABLE 3. ANTIOXIDANT ACTIVITY OF TRANSPARENT \\
SOAPS \\
\hline Transparent soap & DPPH inhibition $(\%) \pm$ SD \\
\hline Control & $0.182 \pm 0.000^{\mathrm{a}}$ \\
S1 & $3.703 \pm 0.105^{\mathrm{b}}$ \\
S2 & $2.004 \pm 0.105^{\mathrm{c}}$ \\
S3 & $1.639 \pm 0.000^{\mathrm{d}}$ \\
S4 & $1.822 \pm 0.000^{\mathrm{e}}$ \\
S5 & $34.244 \pm 0.182^{\mathrm{f}}$ \\
S6 & $0.182 \pm 0.000^{\mathrm{a}}$
\end{tabular}

Note: Values with the same superscript letter are not statistically significant at the 5\% level; SD - standard deviation.

\section{Colour Stability}

The addition of OPAL extracts resulted in an increase in YI of palm-based transparent soap with $0.1 \%$ of OPAL extracts compared to transparent soaps with BHT, green tea extract and control (Figure 3). Besides OPAL extracts, green tea extract was also reported to enhance the colour of transparent soap at $0.5 \%$ concentration (Anggraini et al., 2015). Palm-based transparent soap S2 (soap with OPAL M2) gave the highest YI compared to 


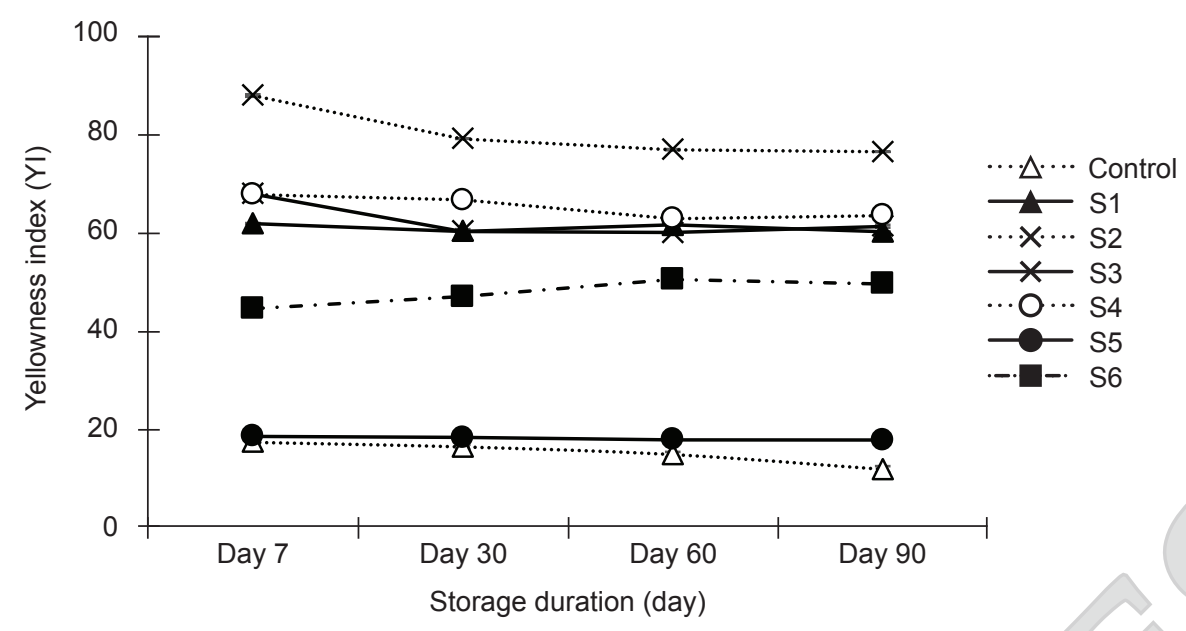

Figure 3. Yellowness index of palm-based transparent soap with $0.1 \%$ of OPAL extracts, BHT and control.

other transparent soaps. Furthermore, the yellow colour of palm-based transparent soap, S1 - S5 remains stable during storage from Day 30 to Day 90. Therefore, OPAL extract can be used as natural yellow colour and the presence of antioxidants in OPAL extract may help in terms of colour stability.

\section{CONCLUSION}

The addition of OPAL extract in transparent soap formulations did not affect foaming power and foam stability. However, transparent soap with OPAL M1 extract showed the highest antioxidant activity than transparent soap with other OPAL extracts and commercial green tea extract. In addition, all OPAL extracts showed stable hardness throughout the study and provided natural yellow colour to the transparent soaps within 90 days of storage.

\section{ACKNOWLEDGEMENT}

The authors are thankful to the Director-General of MPOB for giving the opportunity to publish this article. Special thanks to Mohd Nor Mamat @ Jusoh and Zulkiffli Razali for their assistance.

\section{REFERENCES}

Adigun, O; Manful, C; Prieto Vidal, N; Mumtaz, A; Pham, T H; Stewart, P; Nadeem, M; Keough, D and Thomas, R (2019). Use of natural antioxidants from Newfoundland wild berries to improve the shelf life of natural herbal soaps. Antioxidants, 8(11): 536 (1-19).
Ahmad, N; Azizul Hasan, Z A; Muhamad, H; Bilal, S H; Yusof, N Z and Idris, Z (2018). Determination of total phenol, flavonoid, antioxidant activity of oil palm leaves extracts and their application in transparent soap. J. Oil Palm Res., 30(2): 315-325.

Anggraini, T; Ismanto, S D and Dahlia (2015). The making of transparent soap from green tea extract. Int. J. Adv. Sci. Eng. Inf. Technol, 4: 349-356.

Afsar, Z and Khanam, S (2016). Formulation and evaluation of poly herbal soap and hand sanitizer. Int. Res. J. Pharm., 7(8): 54-57.

Benn, S; Jönsson, $M$ and Willers, $T$ (2017). Benchmarking the foaming properties of a new, mild surfactant formulation according to ASTM D 1173-07. KRÜSS Application Report 283.

Dlova, N C; Naicker, T and Naidoo, P (2017). Soaps and cleansers for atopic eczema, friends or foes? What every South African paediatrician should know about their pH. S. Afr. J. Child Health, 11(3): 146-148.

Emerald, M; Emerald, A; Emerald, L and Kumar, V (2016). Perspective of natural products in skincare. Pharm and Pharmacol Int. J., 4(3): 339-341.

Enujiugha, V N; Talabi, J Y; Malomo, S A and Olagunju, A I (2012). DPPH radical scavenging capacity of phenolic extracts from African yam bean (Sphenostylis stenocarpa). Food Nutr. Sci., 3: 7-13.

Fadda, A; Serra, M; Molinu, M G; Azara, E; Barberis; A and Sanna, D (2014). Reaction time and DPPH concentration influence antioxidant activity and kinetic parameters of bioactive molecules and plant 
extracts in the reaction with the DPPH radical. $J$. Food Compos. Anal., 35(2): 112-119.

Fatiha, M and Abdelkader, T (2019). Study of antioxidant activity of pyrimidinium betaines by DPPH radical scavenging method. J. Anal. Pharm. Res., 8(2): 33-36.

Ghosh, C; Singh, V; Grandy, J and Pawliszyn, J (2020). Development and validation of a headspace needletrap method for rapid quantitative estimation of butylated hydroxytoluene from cosmetics by handportable GC-MS. RSC Adv., 10: 6671-6677.

Hasibuan, S; Sahirman and Ma'ruf, A (2014). The quality of transparent soap from farmer's crude calophyllum seed oil. Int. J. Adv. Sci. Eng. Inf. Technol., 4(5): 47-51.

Irine, R; Nordin, M M; Radzali, M; Azizah, H; Hapizah, N; Mahinda, Y A and Suhaila, M (2003). Antioxidant and hypocholesterolemic effects of Elaeis guineensis frond extract on hypercholesterolemic rabbits. ASEAN Food J, 12: 137-147.

Jaffri, J M; Mohamed, S; Rohimi, N; Ahmad, I N and Noordin, M M (2011). Antihypertensive and cardiovascular effects of catechin-rich oil palm (Elaeis guineensis) leaf extract in nitric oxide-deficient rats. J. Med. Food, 14: 775-783.

Korting, H C and Braun-Falco, O (1996). The effect of detergents on skin $\mathrm{pH}$ and its consequences. Clin. Dermatol., 14: 23-27.

Korting, H C; Hübner, K; Greiner, K; Hamm, G and Braun-Falco, O (1990). Differences in the skin surface $\mathrm{pH}$ and bacterial microflora due to the longterm application of synthetic detergent preparations of $\mathrm{pH} 5.5$ and $\mathrm{pH}$ 7.0. Results of a crossover trial in healthy volunteers. Acta Derm-Venereol., 70(5): 429431.

Kulthanan, K; Maneeprasopchoke, P; Varothai, S and Nuchkull, P (2014). The $\mathrm{pH}$ of antiseptic cleansers. Asia Pac. Allergy, 4(1): 32-36.

Kuntom, A and Kifli, H (1998). Properties of soaps deriyed from distilled palm stearin and palm kernel fatty acids. J. Surfactants Deterg., 1(3): 329-334.

Kuntom, A; Kifli, H and Lim, P K (1996). Chemical and physical characteristics of soap made from distilled fatty acids of palm oil and palm kernel oil. J. Am. Oil Chem. Soc., 73(1): 105-107.

$\mathrm{Ng}, \mathrm{M} \mathrm{H}$ and Choo, Y M (2010). Determination of antioxidants in oil palm leaves (Elaeis guineensis). Am. J. Appl. Sci, 7(9): 1243-1247.
Ong, C; Ibrahim, S and Gupta, B S (2007). A survey of tap water quality in Kuala Lumpur. Urban Water J., 4(1): 1-13.

Osuji, C N; Akunna, T O and Ahaotu, E O (2013). Use of palm oil sludge in toilet soap production. Inter. J. Appl. Sci. Engr., 1(2): 73-78.

Parveez, G K A; Hishamuddin, E; Loh, S K; OngAbdullah, M; Salleh, K M; Zanal Bidin, M N I; Sundram, S; Hasan, Z A A and Idris, Z (2020). Oil palm economic performance in Malaysia and $R \& D$ progress in 2019. J. Oil Palm Res., 32(2): 159-190.

Rhim, J W; Wu, Y; Weller, C L and Schnepf, M (1999). Physical characteristics of a composite film of soy protein isolate and propylene glycol alginate. J. Food Sci., 64(1): 149-152.

Ribeiro, AS; Estanqueiro, M; Oliveira, M B and Lobo, J M S (2015). Main benefits and applicability of plant extracts in skincare products. Cosmetics, 2: 48-65.

Srinivasan, G; Srinivas, C R; Mathew, A C and Duraiswami, D (2013). Effects of hard water on hair. Int. J. Thricol., 5(3): 137-139.

Takagi, Y; Kaneda, K; Miyaki, M; Matsuo, K; Kawada, H and Hosokawa, H (2015). The long-term use of soap does not affect the $\mathrm{pH}$-maintenance mechanism of human skin. Skin Res. Technol., 21(2): 144-148.

Vivian, O P; Nathan, O; Osano, A; Mesopirr, L and Omwoyo, W N (2014). Assessment of the physicochemical properties of selected commercial soaps manufactured and sold in Kenya. Open J. Appl. Sci., 4(8): 433-440.

Wijetunge, W M A N K and Perera, B G K (2016). Preparation of medicinal soap products using the leaf extracts of Punica granatum (pomegranate). Int. J. Pharm. Biol. Sci., 6(2): 7-16.

Wolfrum, S; Marcus, J; Touraud, D and Kunz, W (2016). A renaissance of soap? - How to make clear and stable solutions at neutral $\mathrm{pH}$ and room temperature. Adv. Colloid Interface Sci., 236: 28-42.

Yamaki, K; Taneda, S; Yanagisawa, R; Inoue, K; Takano, H and Yoshino, S (2007). Enhancement of allergic responses in vivo and in vitro by butylated hydroxytoluene. Toxicol. Appl. Pharmacol., 223(2): 164-172.

Yusof, N Z; Abd Gani, S S; Siddiqui, Y; Mohd Mokhtar, NF and Azizul Hasan, Z A (2016). Potential uses of oil palm (Elaeis guineensis) leaf extract in topical application. J. Oil Palm Res., 28(4): 520-530. 